\title{
高温水中に拈ける $\mathrm{Nb}$ 添加による Alloy 600 の
}

\section{応力腐食割れ抵抗性の改良}

\author{
山 中 和 夫* 小 川 和 博** \\ 南孝 男** 長 野 博 夫**
}

\section{Improvement of Stress Corrosion Cracking Resistance of Alloy 600 by Niobium Addition in High Temperature Water}

by

\author{
Kazuo YamanaKA*, Kazuhiro OGaWA**, Takao Minami** \\ and Hiroo NAGANO**
}

\begin{abstract}
The effect of niobium as a stabilizing element and the effect of thermal cycles on welding of the corrosion resistance of $75 \% \mathrm{Ni}-15 \% \mathrm{Cr}$ (Alloy 600 ) were investigated. The results are summarized as follows :

(1) The effects of weld thermal cycle and sensitizing heat treatment on the intergranular corrosion (IGC) and intergranular stress corrosion cracking (IGSCC) of Alloy 600 containing carbon more than $0.01 \mathrm{wt} \%$ can be explained by the behavior of chromium carbide precipitation at the grain boundaries.

(2) In Alloy 600 containing carbon more than $0.01 \mathrm{wt} \%$, a suitable addition of niobium $(\mathrm{Nb} / \mathrm{C} \geq 30$ ) prevents degradation of corrosion resistance due to the sensitization caused by the chromium carbide precipitation.
\end{abstract}

Key words : Ni-based alloy 600, Stress corrosion cracking, Sensitization, High temperature water, Weld thermal cycle, Stabilizing element, Chromium depletion, Intergranular cracking

\section{1 緒言}

$\mathrm{Ni}$ 基 600 合金は $\mathrm{Fe}$ 基のオーステナイトステンレ ス鋼に比べて炭素の固溶度が小さいため, 溶接熱サイ クル等の熱履歴によりクロム炭化物が析出しやすいこ とが報告されている。非脱気高温水中での 600 合金の 粒界応力腐食割れ（IGSCC）については，オーステ ナイト系ステンレス鋼のそれと同様，鋭敏化熱履歴に より IGSCC 感受性が高まることからクロム炭化物の 粒界析出にともなう $\mathrm{Cr}$ 欠乏層の形成に起因する割れ であると考えられている。本報告は 600 合金ベースで $\mathrm{Cr}$ 欠乏層の形成を抑制するために安定化元素として $\mathrm{Nb}$ を添加した合金の炭化物析出挙動と耐粒界腐食性 および $\mathrm{Cl}^{-}$含有非脱気高温水中の耐 IGSCC 性との関 係を調査した。

\section{$2 \cdot 1$ 供試材}

\section{2 実 験 方 法}

供試材の化学組成を Table I に示す. $75 \% \mathrm{Ni}$ - $15 \% \mathrm{Cr}$ をべースとして $\mathrm{Nb}$ および $\mathrm{C}$ 量を $\mathrm{Nb} / \mathrm{C}$ 比で $0 \sim 92$ まで変化させたものを真空溶解した．な
お, No. 3 と No. 10 の試料のみは現場溶製材で VOD (真空脱炭) 处理工程を経ている. 厚さ $12 \mathrm{~mm}$ および $4.9 \mathrm{~mm}$ の 2 種類の板に鍛造, 熱延, 冷却した. 各工 程の製造条件は次の通りである。鍛造は $30 \mathrm{~mm}$ 厚ま で $1453 \mathrm{~K}$ 加熱, $1273 \mathrm{~K}$ 仕上りで行い, 熱延は $17 \mathrm{~mm}$ 厚または $7 \mathrm{~mm}$ 厚まで $1453 \mathrm{~K}$ 加熱, $1223 \mathrm{~K}$ 仕上りで 行った. ついで $1323 \mathrm{~K}-1.8 \mathrm{ks}\left(1050^{\circ} \mathrm{C}-0.5 \mathrm{~h}\right)$ 水冷の 中間焼なましを行ったのち約 $30 \%$ の冷間圧延を行っ た.ついでアルゴンガス雲囲気中 $1223 \mathrm{~K}-1.2 \mathrm{ks}$ $\left(950^{\circ} \mathrm{C}-20 \mathrm{~min}\right)$ 空冷の焼なましを行い, さらにLTS (低温鋭敏化) $+\mathrm{SR}$ (応力除去熱処理を考慮した $823 \mathrm{~K}$ $-54 \mathrm{ks}\left(550^{\circ} \mathrm{C}-15 \mathrm{~h}\right)$ の熱処理と $873 \mathrm{~K}-72 \mathrm{ks}\left(600^{\circ} \mathrm{C}\right.$ -20h)の強鋭敏化熱処理を施した. 耐食性試験は母 材, 溶接再現熱サイクル材および TIG 溶接材につい て行った.

\section{$2 \cdot 2$ 溶接再現熱サイクル試験}

厚さ $12 \mathrm{~mm}$ の焼なまし材を用いて, 高周波誘導加 熱により単層溶接を模した単一熱サイクルと多層溶接 を模した二重熱サイクルおよびそれぞれに LTS

原稿受理 昭和62年 4月 8 日 $\quad$ Received Apr. 8, 1987

* 正 会 員 住友金属工業(株)総合技術研究所 尼崎市西長州本通, Technical Research Laboratories, Sumitomo Metal Industries, Ltd., Nishinagasu-hondori, Amagasaki

** 住友金属工業(株)総合技術研究所 尼崎市西長州本通, Technical Research Laboratories, Sumitomo Metal Industries, Ltd., Nishinagasuhondori, Amagasaki 
Table I. Chemical compositions of alloys (wt\%).

\begin{tabular}{|c|c|c|c|c|c|c|c|c|c|c|c|c|}
\hline Alloy & $\begin{array}{l}\text { Specimen } \\
\text { No. }\end{array}$ & $\mathrm{C}$ & $\mathrm{Si}$ & $\mathrm{Mn}$ & $\mathbf{P}$ & $\mathrm{S}$ & $\mathrm{Ni}$ & $\mathrm{Cr}$ & $\mathrm{Nb}$ & $\mathrm{Al}$ & $\mathrm{N}$ & $\mathrm{Nb} / \mathrm{C}$ \\
\hline \multirow{3}{*}{$\mathrm{Nb}$-free } & 1 & 0.004 & 0.44 & 0.37 & 0.001 & 0.001 & 73.54 & 15.47 & - & 0.107 & 0.0016 & - \\
\hline & 2 & 0.007 & 0.41 & 0.41 & 0.001 & 0.001 & 73.15 & 15.56 & - & 0.137 & 0.0019 & - \\
\hline & 3 & 0.024 & 0.36 & 0.28 & 0.010 & 0.001 & 74.75 & 15.95 & - & 0.080 & 0.0065 & - \\
\hline \multirow{3}{*}{$<0.01 \% \mathrm{C}-\mathrm{Nb}$} & 4 & 0.005 & 0.41 & 0.42 & 0.001 & 0.001 & 74.01 & 15.52 & 0.23 & 0.143 & 0.0019 & 46.0 \\
\hline & 5 & 0.008 & 0.42 & 0.44 & 0.001 & 0.001 & 74.17 & 15.46 & 0.46 & 0.146 & 0.0027 & 57.5 \\
\hline & 6 & 0.005 & 0.43 & 0.42 & 0.001 & 0.002 & 73.79 & 15.36 & 0.46 & 0.145 & 0.0018 & 92.0 \\
\hline \multirow{4}{*}{$\begin{array}{c}0.01 \sim 0.02 \% \mathrm{C} \\
-\mathrm{Nb}\end{array}$} & 7 & 0.014 & 0.42 & 0.41 & 0.001 & 0.001 & 73.83 & 15.52 & 0.24 & 0.137 & 0.0021 & 17.1 \\
\hline & 8 & 0.015 & 0.42 & 0.42 & 0.001 & 0.002 & 75.09 & 15.26 & 0.45 & 0.129 & 0.0029 & 30.0 \\
\hline & 9 & 0.016 & 0.43 & 0.40 & 0.001 & 0.002 & 74.33 & 15.48 & 0.70 & 0.146 & 0.0033 & 43.7 \\
\hline & 10 & 0.010 & 0.31 & 0.34 & 0.008 & 0.001 & 74.50 & 15.30 & 0.54 & 0.140 & 0.0063 & 54.0 \\
\hline \multirow{2}{*}{$\begin{array}{c}0.02 \sim 0.03 \% \mathrm{C} \\
-\mathrm{Nb}\end{array}$} & 11 & 0.020 & 0.41 & 0.41 & 0.001 & 0.001 & 73.86 & 15.48 & 0.24 & 0.148 & 0.0021 & 12.0 \\
\hline & 12 & 0.021 & 0.41 & 0.41 & 0.001 & 0.001 & 74.69 & 15.56 & 0.71 & 0.142 & 0.0028 & 33.8 \\
\hline \multirow{4}{*}{$\begin{array}{c}0.03 \sim 0.04 \% \mathrm{C} \\
-\mathrm{Nb}\end{array}$} & 13 & 0.034 & 0.41 & 0.41 & 0.001 & 0.001 & 74.81 & 15.48 & 0.25 & 0.142 & 0.0021 & 7.3 \\
\hline & 14 & 0.035 & 0.41 & 0.43 & 0.001 & 0.002 & 74.10 & 15.57 & 0.46 & 0.145 & 0.0025 & 13.1 \\
\hline & 15 & 0.032 & 0.43 & 0.42 & 0.001 & 0.001 & 74.81 & 15.48 & 0.46 & 0.150 & 0.0023 & 14.3 \\
\hline & 16 & 0.040 & 0.41 & 0.42 & 0.001 & 0.002 & 75.99 & 15.41 & 0.70 & 0.154 & 0.0038 & 17.5 \\
\hline
\end{tabular}

した. 試験後二重 U 字 曲げの内側試験片の断面 を光学顕微鏡観察し, 最 大割れ深さを測定した。

\section{$2 \cdot 5$ 粒界腐食試験}

600 合金は $\mathrm{Cr}$ 含有量 が 15\% と低いため, オーステナイトステンレ ス鋼に対して用いられて いる粒界腐食試験法（沸 騰 $65 \% \mathrm{HNO}_{3}$ 溶液浸漬) をそのまま適用しにくい. そのため 600 合金の粒界 腐食感受性について $\mathrm{HNO}_{3}$ 濃度の影響を調べ, $40 \%$ が適正であること が判明しだたで, 本研究 では厚さ $4.9 \mathrm{~mm}$ の板か
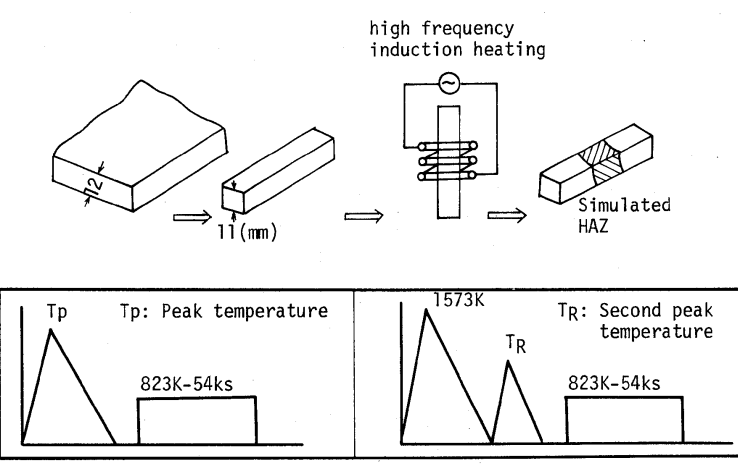

(a) Single thermal cycle

(b) Double thermal cycle

Fig. 1. Schematic diagram of simulated HAZ test.

$+\mathrm{SR}$ を考慮した熱処理 $(823 \mathrm{~K}-54 \mathrm{kS})$ を組み合せた 4 種類の熱サイクル（Fig. 1) を付与した試料を作成 した.

\section{$2 \cdot 3$ TIG 溶接試験}

厚さ $4.9 \mathrm{~mm}$ の焼なまし材を用いて, 電流 $60 \mathrm{~A}$, 電 圧 $15 \mathrm{~V}, 3.3 \mathrm{~mm} / \mathrm{s}$ の速度でアルゴンシールガス中 TIG ビードオン溶接を行い, その表面層から腐食試 験片を溶接金属部が中央部に位置するように採取した。

\section{$2 \cdot 4$ 応力腐食割れ試験}

厚さ $4.9 \mathrm{~mm}$ の板から圧延方向に平行に板厚中央部 から $2^{t} \mathrm{~mm} \times 10^{w} \mathrm{~mm} \times 75^{l} \mathrm{~mm}$ の短冊型試験片を切り出 した.この試験片を 2 枚重ね, 半径 $7.5 \mathrm{~mm}$ で $\mathrm{U}$ 字型 に曲げ，さらに $5 \mathrm{~mm}$ 拘束した. いわゆる二重 U 字曲 げ試験片を用い，500 $\mathrm{ppmCl}^{-}$を含有する非脱気（室 温で $8 \mathrm{ppm}$ の溶存酸素), $573 \mathrm{~K}\left(300^{\circ} \mathrm{C}\right)$ の高温水中に $3600 \mathrm{ks}(1000 \mathrm{~h})$ 浸漬し, SCC 試験を行った. 静置型 オートクレーブを使用し $720 \mathrm{ks}(200 \mathrm{~h})$ ごとに液を更新

ら圧延方向に平行に板厚中央部から $3^{t} \mathrm{~mm}$ $\times 10^{w} \mathrm{~mm} \times 40^{l} \mathrm{~mm}$ 切り出した短冊試験片を沸 騰 $40 \% \mathrm{HNO}_{3}$ 溶液中に $86.4 \mathrm{ks}(24 \mathrm{~h})$ 浸漬した. 試験後試験片の断面を光学顕微鏡観察し, 最大 粒界侵食深さを測定した。また腐食減量も測定 した.

\section{$2 \cdot 6$ 磁化率測定}

精密磁気天秤を用い, 外部磁場 $1300 \mathrm{Oe} に$ おける磁化率を測定した。試験片は $4^{\Phi} \times 5^{l} \mathrm{~mm}$ であった.

\section{$2 \cdot 7$ 炭化物観察}

炭化物の析出状況を抽出レプリカ電顕により 観察した. 試料からの炭化物の抽出は王水 $\left(\mathrm{HCl}: \mathrm{HNO}_{3}:\right.$ グリセリン $\left.=1: 1: 2\right)$ で腐食した試料 にカーボン蒸着し， $3 \%$ ブロムアルコールで抽出する， いわゆる抽出レプリカ法によった。

\section{3 実験結果および考察}

\section{$3 \cdot 1$ 母材の耐食性に及ぼす $\mathrm{Nb}$ の影響}

$\mathrm{Nb}$ 添加した 600 合金の粒界腐食試験結果を Fig. 2 に示す. $\mathrm{Nb} / \mathrm{C}$ 比を種々変化させた $\mathrm{Nb}$ 添加 600 合金 の耐粒界腐食性は $\mathrm{Nb} / \mathrm{C}$ 比が大きくなるにしたがっ て良好になっている，すなわち LTS +SR を考慮し た $823 \mathrm{~K}-54 \mathrm{ks}$ の熱処理を施した材料では $\mathrm{Nb} / \mathrm{C}$ 比 が約 20 倍以上で粒界侵食は生ぜず耐粒界腐食性が良 好である.ささらに強鋭敏化熱処理 $(873 \mathrm{~K}-72 \mathrm{ks})$ を施 した場合は $\mathrm{Nb} / \mathrm{C}$ 比が約 40 倍以上で粒界侵食が生じ にくくなっている.

つぎに $\mathrm{Cl}^{-}$含有高温水中に扮ける $\mathrm{Nb} / \mathrm{C}$ 比を種々 変化させた $\mathrm{Nb}$ 添加 600 合金の SCC 試験結果を Fig. 3 に示す. 強鋭敏化熱处理を施しても $\mathrm{Nb} / \mathrm{C}$ が 30 な 


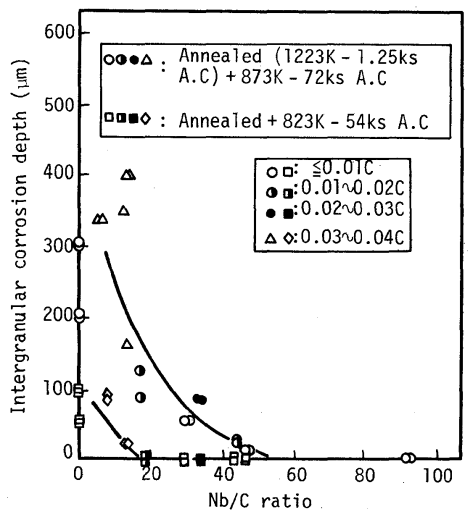

Fig. 2. Effect of $\mathrm{Nb} / \mathrm{C}$ ratio of $75 \% \mathrm{Ni}-15 \% \mathrm{Cr}-\mathrm{Nb}$ alloys on the intergranular corrosion depth in boiling $40 \% \mathrm{HNO}_{3}$ solution for $86.4 \mathrm{ks}(24 \mathrm{~h})$.

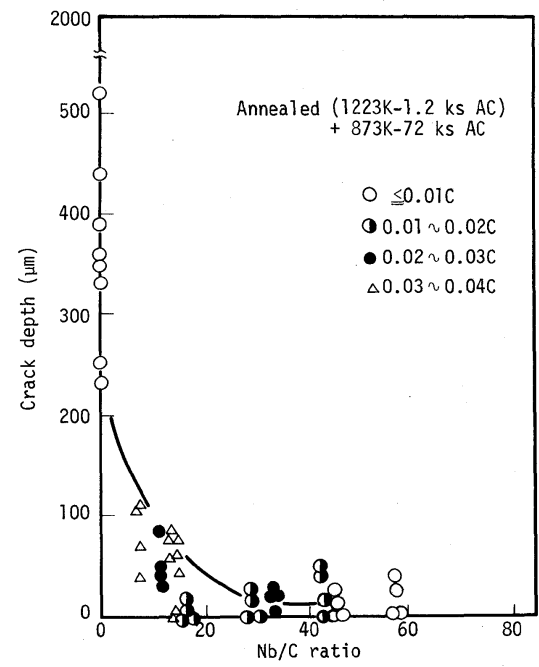

Fig. 3. Effect of $\mathrm{Nb} / \mathrm{C}$ ratio of $75 \% \mathrm{Ni}-15 \% \mathrm{Cr}-\mathrm{Nb}$ alloys on SCC crack depth in non-deaerated water containing $500 \mathrm{ppm} \mathrm{Cl}^{-}$at $573 \mathrm{~K}$ for $3600 \mathrm{ks}$ $(1000 \mathrm{~h})$
いし 40 倍以上で IGSCC は約 $50 \mu \mathrm{m}$ 以下となり耐 IGSCC 性が良好となり，耐粒界腐食性と同じような 結果を得た.このような $\mathrm{Nb}$ 添加による耐食性向上効 果は, 後述するように $\mathrm{Nb}$ による固溶 C の固定作用, すなわち安定化作用によって固溶 $\mathrm{C}$ 量が減少し, 鋭 敏化熱処理を施してもクロム炭化物が生成しがたく なっているためであろうと考えられる. なお, Fig. 3 で $\mathrm{Nb} / \mathrm{C}$ 比が 60 倍程度と固溶 $\mathrm{C}$ の固定に十分と思わ れる $\mathrm{Nb}$ を添加しても C 量が約 $0.01 \mathrm{wt} \%$ 以下の極低 炭素合金ではなお約 $50 \mu \mathrm{m}$ 程度の微小割れが認められ る理由は微量不純物元素の粒界偏析などの影響に起因 するものであろうと思われるが，本研究では明らかに することができなかった。

\section{$3 \cdot 2$ 溶接部の耐食性に及ぼす $\mathrm{Nb}$ の影響}

(1) 溶接再現 HAZ 材の耐食性 Table I 中の試料 No. 3 の Nb 無添加 600 合金と試料 No. 10 の $0.54 \%$ $\mathrm{Nb}$ 添加 600 合金について溶接再現 HAZ 材の耐食性 をクロム炭化物の析出挙動との関係において調査した. Fig. 4 に溶接再現 HAZ 材の粒界腐食試験結果を示す.

$\mathrm{Nb}$ 無添加の通常の 600 合金でも熱サイクルのまま では粒界腐食は生じにくいが, $823 \mathrm{~K}-54 \mathrm{kS}$ の熱処理 を施すと耐粒界腐食性は劣化し，特に二重熱サイクル 材でその劣化が著しい.この熱サイクルと粒界腐食と の関係は粒界におけるクロム炭化物 $\left(\mathrm{Cr}_{23} \mathrm{C}_{6}\right)$ の析出 状況と定性的に一致している.すなわち単一熱サイク ル材においては Fig. 5 に示すように熱サイクル前の素 材は比較的粗大な未固溶ク口ム炭化物 $\left(\mathrm{Cr}_{7} \mathrm{C}_{3}\right.$ と同 定）が点在している組織であるが，ピーク温度が高く なると共に未固溶クロム炭化物が次第にマトリックス へ固溶してゆき，その量が減少している．この熱サイ クルのままの状態では粒界への新たなクロム炭化物の 生成がほとんどみられず耐粒界腐食性は良好である.

しかしながらここの熱サイクル材にLTS+SR を考
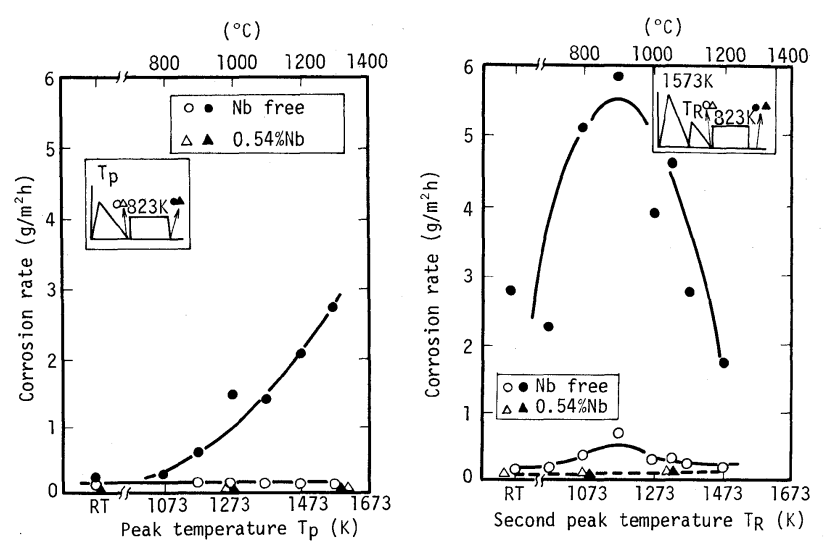

Fig. 4. Effect of thermal cycle of $75 \% \mathrm{Ni}-15 \% \mathrm{Cr}$ and $75 \% \mathrm{Ni}-15 \% \mathrm{Cr}$ $0.54 \% \mathrm{Nb}$ alloys on corrosion rate in boiling $40 \% \mathrm{HNO}_{3}$ solosion for $86.4 \mathrm{ks}(24 \mathrm{~h})$
慮した $823 \mathrm{~K}-54 \mathrm{ks}$ の熱処理を施すと ピーク温度の上昇と共に $\mathrm{Cr}_{23} \mathrm{C}_{6}$ から成 る新たなクロム炭化物の粒界析出量が増 加する傾向を示し, 腐食速度の増加（耐 粒界腐食性の劣化）とよい対応を示した.

二重熱サイクル材については最初の熱 サイクル（1573K 加熱）で未固溶炭化 物が完全にマトリックスに固溶してしま うため, 二回目の熱サイクルと $823 \mathrm{~K}-54 \mathrm{ks}$ の熱処理を施した場合に粒 界へのクロム炭化物の核生成 - 成長が 起こる. 特にFig. 6 に示すようにクロム 炭化物の析出が最も生じやすい 973 1273K の温度で顕著に生じ, Fig. 4 の耐 粒界腐食性の劣化とよい対応を示した。 


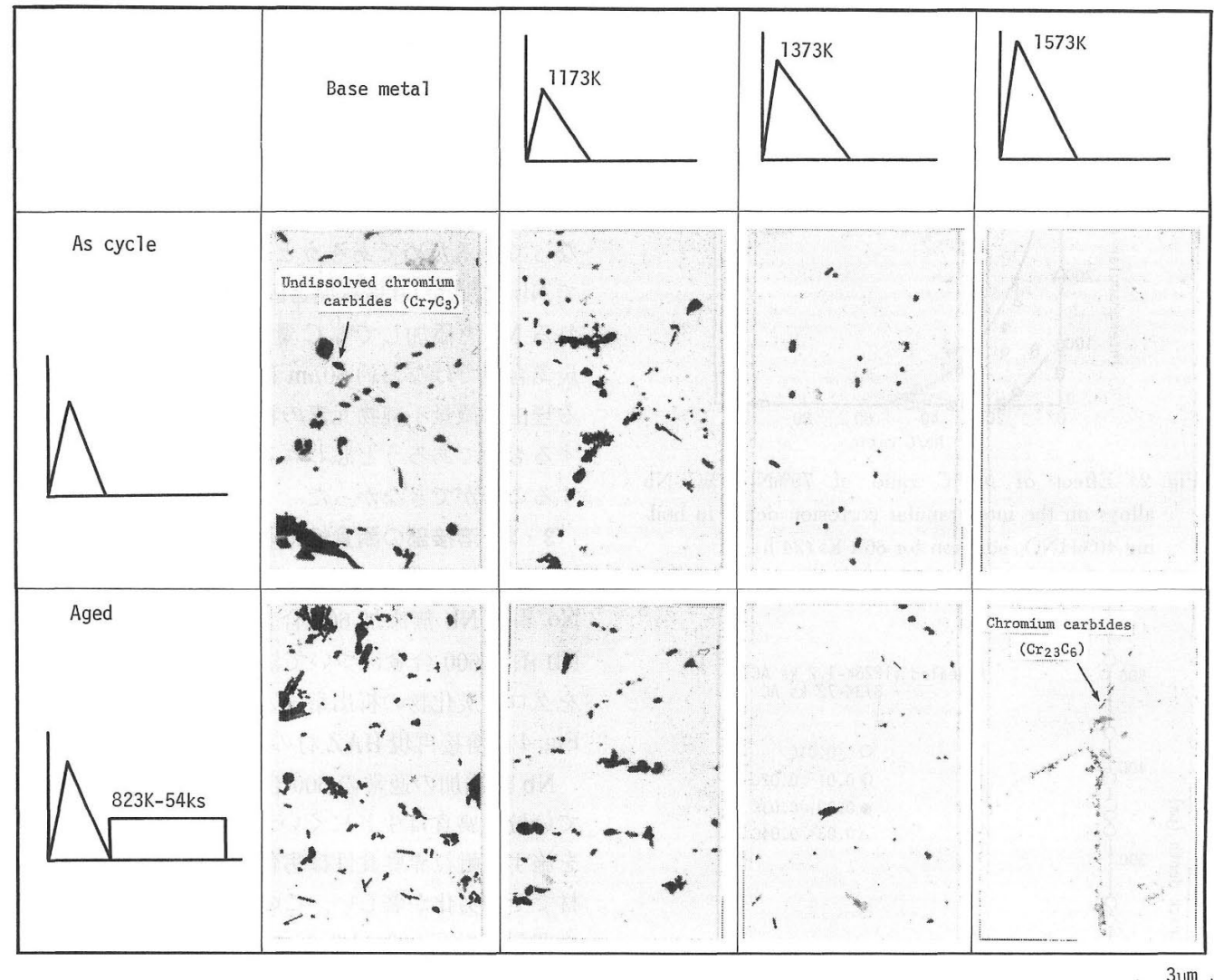

Fig. 5. Electron micrographs of carbide precipitation of simulated HAZ (single thermal cycle) of $0.024 \% \mathrm{C}-75 \% \mathrm{Ni}-15 \% \mathrm{Cr}$ alloy.

SCC 試験結果も Fig. 7 に示すように粒界腐食挙動と 同様な傾向を示した.

これらの結果から熱サイクルの作用は母忉に存在し ていた未固溶クロム炭化物のマトリックスへの固溶と 粒界へのクロム炭化物の核生成であり，この二つの作 用によりその後の $823 \mathrm{~K}$ 熱処理時に鋭敏化が促進され たものと考えられる. Fig. 8 に二重熱サイクル材の熱 履歷と組織（とくにクロム炭化物の生成状況）との関 係を模式的に示す。

一方, $\mathrm{Nb}$ 添加 $(0.54 \% \mathrm{Nb}) 600$ 合金では $\mathrm{Nb}$ 無添 加 600 合金で最も鋭敏化の促進される熱サイクル条件 でもFig. 9 に示す電顕写真からわかるようにクロム炭 化物の粒界析出が全く認められず，Fig. 4 や 7 の のように耐粒界腐食抢よび耐 IGSCC 性が良好である

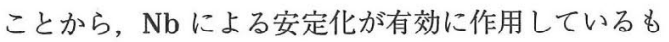
のと判断される.

完全オーステナイトである 600 合金のような $\mathrm{Ni}$ 基 合金においてもクロム欠乏層の存在により磁化率が変 化することはすでに岡田らによっって報告されている. そこでこの磁化率測定を溶接再現 HAZ 材で行うこと
によってその鋭敏化挙動と Fig. 4 や 7 の耐食性のデー 夕との相関性を調べた. Fig. 10 に再現 HAZ 材の嗞化 率測定結果を示す。二重熱サイクル材では粒界腐食や IGSCC 特性と打扔むね一致しているが，単一熱サイ クルを与えた $\mathrm{Nb}$ 無添加 600 合金では一致していない． この理由としては粒内に未固溶クロム炭化物が存在す る組織では，新たに生成するクロム炭化物は粒界以外 にこれら未固溶クロム炭化物も析出のサイトとなり, 粒内にもクロム欠乏層が生じているためであろうと考 えられる。

(2) 溶接 HAZ 部の耐食性 TIG ビードオン溶接継 手の $\mathrm{HAZ}$ 部の耐食性を $\mathrm{Nb} / \mathrm{C}$ 比を種々変化させた $\mathrm{Nb}$ 添加 600 合金に対して調査した. Fig. 11 にSCC 試験結果を示す，TIG ビードオン溶接継手の HAZ 部 の耐 IGSCC 性は Fig. 3 に示した強鋭敏化処理材の耐 IGSCC 性とほぼ同様な挙動を示し, $\mathrm{Nb} / \mathrm{C}$ 比が执よ そ 30 倍以上で良好となることが確認された。

\section{$3 \cdot 3 \mathrm{Nb}$ 炭穻化物の析出挙動}

$\mathrm{Nb}$ 添加 600 合金における $\mathrm{Nb}(\mathrm{C}, \mathrm{N})$ の等温析出挙 動を $0.54 \% \mathrm{Nb}$ 添加 600 合金（試料 No. 10）を用い 


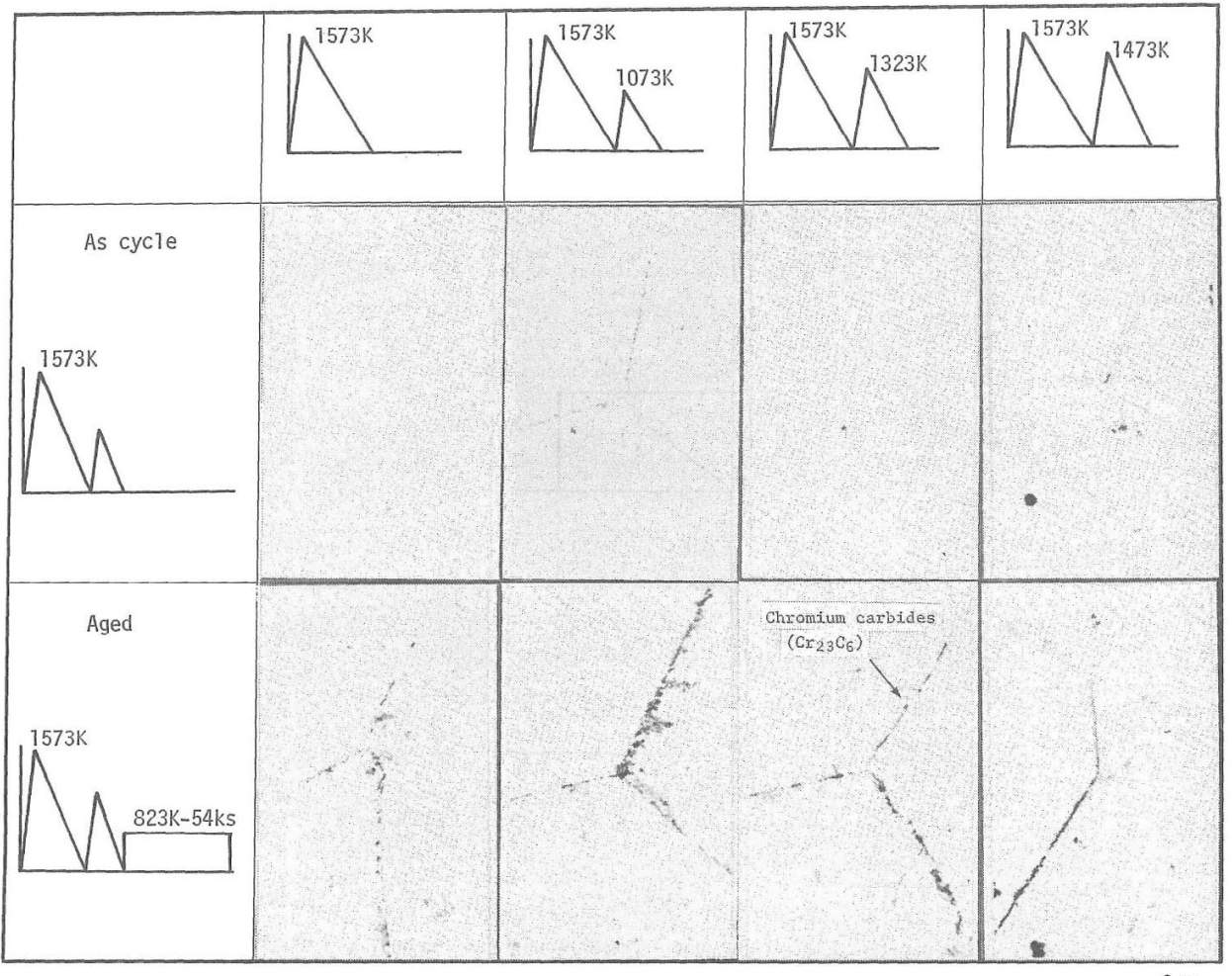

3um

Fig. 6. Electron micrographs of carbide precipitation of simulated HAZ (double thermal cycle) of $0.024 \% \mathrm{C}-75 \% \mathrm{Ni}-15 \% \mathrm{Cr}$ alloy.
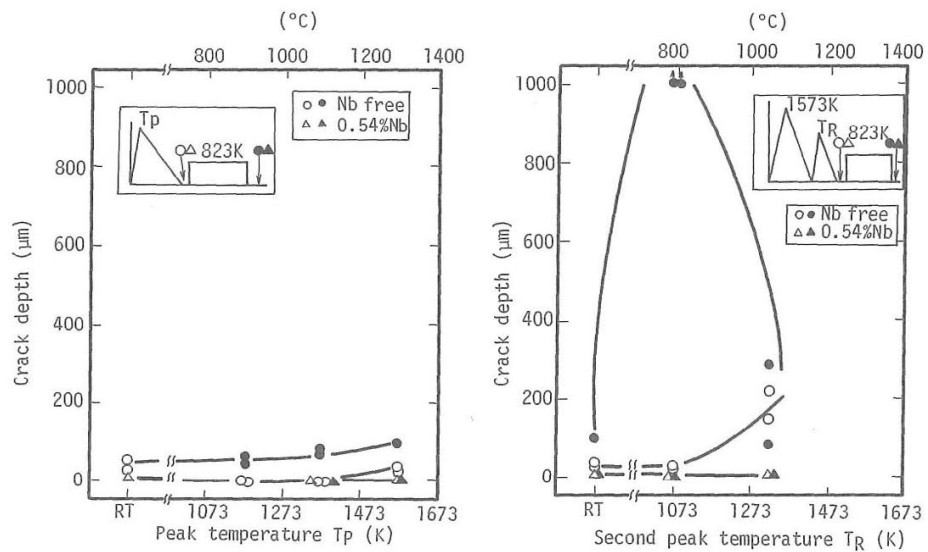

Fig. 7. Effect of thermal cycle of $75 \% \mathrm{Ni}-15 \% \mathrm{Cr}$ and $75 \% \mathrm{Ni}-15 \% \mathrm{Cr}-0.54 \% \mathrm{Nb}$ alloys on $\mathrm{SCC}$ crack depth in nondeaerated water containing $500 \mathrm{ppm} \mathrm{Cl}-$ at $573 \mathrm{~K}$ for $3600 \mathrm{ks}(1000 \mathrm{~h})$.

て抽出レプリカ電顕により調査した。 $\mathrm{Nb}(\mathrm{C}, \mathrm{N})$ の等 温析出挙動は Fig. 12 に示すように温度，保持時間に 対してC 型曲線を示して扔り，1173〜1373K の温 度域に扔いて析出しやすく, とくに $1223 \sim 1323 \mathrm{~K}$ の温度域では極めて短時間のうちに析出する。析出形 態は温度によって多少ちがいがみられるようであり， 抒扮まかには高温側から粒状，棒状または針状，微細
な粒状または糸状の順であるが，粒界に析出するもの は必ずしも形態が定まっていないようである。

600 合金に扔けるクロム炭化物の等温析出挙動はす でに報告されているように，拉よそ773～1173Kの 温度域に扔いて析出しやすく, $\mathrm{Nb}(\mathrm{C}, \mathrm{N})$ の析出しや すい 1173 ～1373K の温度に比べて低温域に位置し ている。このため, $\mathrm{Nb}$ 添加 600 合金を 1173 〜 


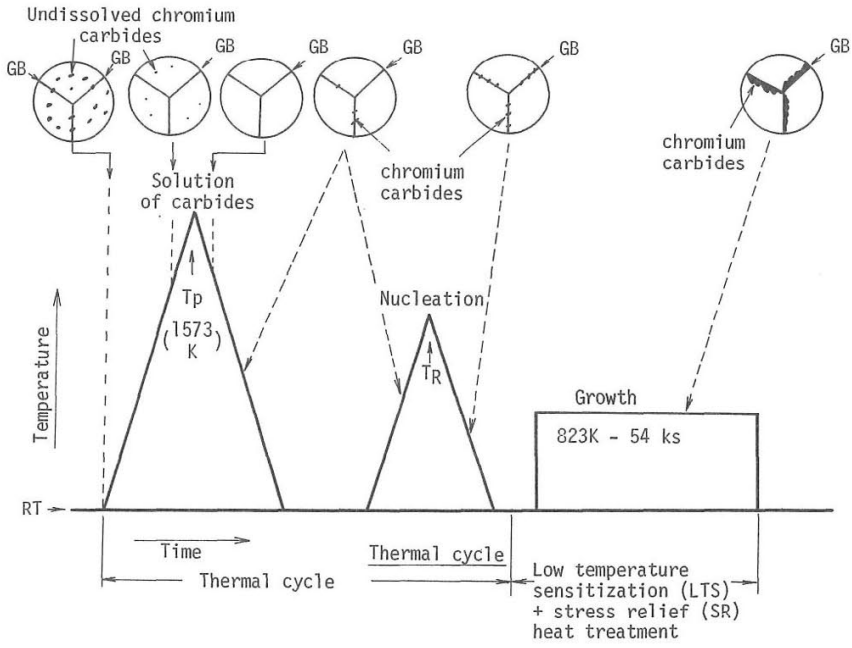

Fig. 8. Schematic diagram of morphological changes of carbides during weld simulated double thermal cycles.

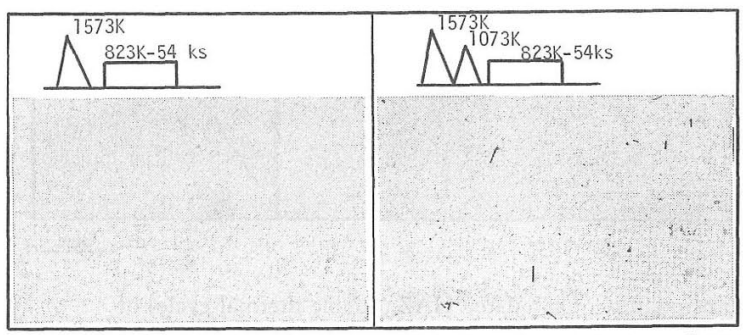

(a) Single thermal cycle

(b) Double thermal cycles $\llcorner 3$ um

Fig. 9. Electron micrographs of simulated HAZ (single and double thermal cycles) of $75 \% \mathrm{Ni}-15 \% \mathrm{Cr}-0.54 \% \mathrm{Nb}$ alloy.

$\left({ }^{\circ} \mathrm{C}\right)$

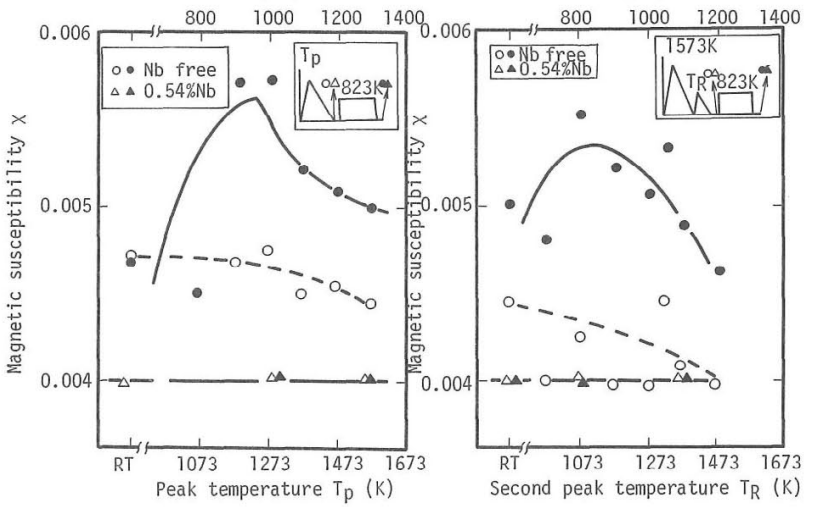

Fig. 10. Effect of thermal cycles on magnetic susceptibility of $75 \% \mathrm{Ni}$ $-15 \% \mathrm{Cr}-0.54 \% \mathrm{Nb}$ alloys measured at room temperature.

1373K の温度域で熱処理するか，あるいは溶接熱サ イクルのように高温からこの温度域を横切る熱履歴を うけると固溶 $\mathrm{C}$ や $\mathrm{N}$ の多くはまず $\mathrm{Nb}$ と結びついて $\mathrm{Nb}(\mathrm{C}, \mathrm{N})$ として析出することになるため，合金中の 固溶 C 量が減少し, その後のクロム炭化物の生成し やすい 773 ～1173K の温度での熱履歴を受けても容
易にはクロム炭化物が量的にも時間的 にも析出しにくいように考えられる。

$3 \cdot 1$ や $3 \cdot 2$ 節で $\mathrm{Nb}$ 添加 600 合金の 耐食性がすぐれる理由はこのためであ ろうと思われる。

このように $\mathrm{Nb}$ 添加による安定化効 果は 600 合金のような $\mathrm{Ni}$ 基合金にお いてもステンレス鋼と同じように大き いことが認められた。 $\mathrm{Nb}$ と同じよう な安定化作用を有する Ti と比べると, 少なくとも 600 合金においては $\mathrm{Ti}$ り $\mathrm{Nb}$ の方が安定化效果，すなわち固 溶 C の固定作用が大きいように思わ れる。.

このことに関して $\mathrm{Ni}$ 基合金では $\mathrm{Ti}-\mathrm{C}$ および $\mathrm{Nb}-\mathrm{C}$ の溶解度積に関 するデー夕はまだ得られていないよう であるので，オーステナイトステンレ ス鋼ですでに得られている溶解度積 $\left(\mathrm{Ti}-\mathrm{C}: \log _{10}[\mathrm{Ti}][\mathrm{C}]=-8900 / \mathrm{T}+\right.$ 4.46, $\mathrm{Nb}-\mathrm{C}_{9)}: \log _{10}[\mathrm{Nb}][\mathrm{C}]=$ $-15110 / \mathrm{T}+8.28)$ を用いて固溶 $\mathrm{C} の$ 固定効果の平衡状態での計算を行った 計算結果は Fig. 13 に示すように Nb は Ti に比べて固溶 C の固定作用が大 きいことを示しており，600 合金のよ うな $\mathrm{Ni}$ 基合金においてもオーステナ イトステンレス鋼と同じような Nbの 働きがあるように推察される。

\section{4 結 論}

（1） C 量をおよそ $0.01 \mathrm{wt} \%$ 以上含 有した $\mathrm{Ni}$ 基 600 合金の溶接熱サイク ル等の熱履歴による耐食性劣化は，炭 化物析出挙動によって説明することが でき，安定化元素としての Nb を適正 量添加することによって耐食性劣化を 防止できる。

(2) C 量がおよそ0.01wt\% 以上の 600 合金において $\mathrm{Nb}$ を $\mathrm{Nb} / \mathrm{C}$ 比でお よそ 30 倍以上添加した改良 600 合金 は $\mathrm{Cl}^{-}$含有非脱気高温水中で母材㧍よ び溶接 HAZ 部共に耐応力腐食割れ性 が良好である。

(3) $\mathrm{Nb}$ 添加した改良 600 合金における $\mathrm{Nb}(\mathrm{C} ， \mathrm{~N})$ はおよそ 1223 ～1323K の温度において最も析出が 速い.

（昭和62年 3 月 12 日 腐食防食部門委員会第137回例会にて講演） 

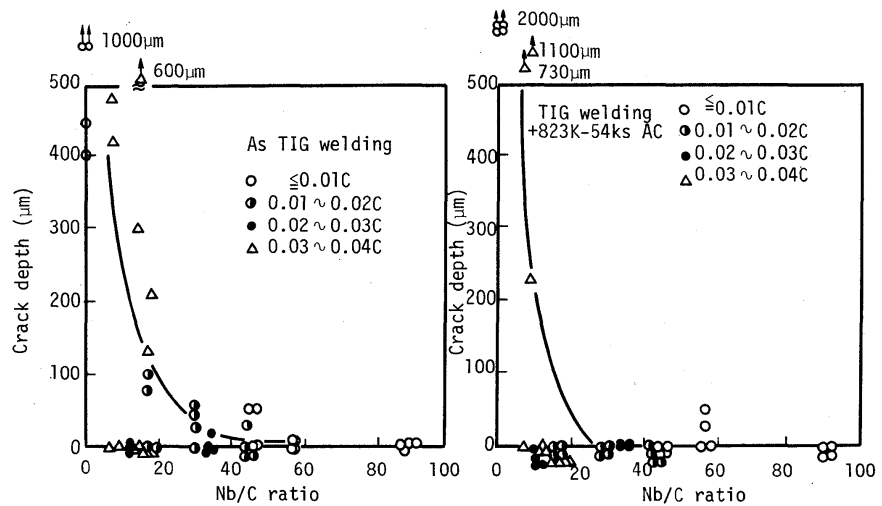

Fig. 11. Effect of $\mathrm{Nb} / \mathrm{C}$ ratio on the $\mathrm{SCC}$ crack depth of $75 \% \mathrm{Ni}-15 \% \mathrm{Cr}-\mathrm{Nb}$ alloys in non-deaerated water containing $500 \mathrm{ppm} \mathrm{Cl}^{-}$at $573 \mathrm{~K}$ for $3600 \mathrm{ks}(1000 \mathrm{~h})$.

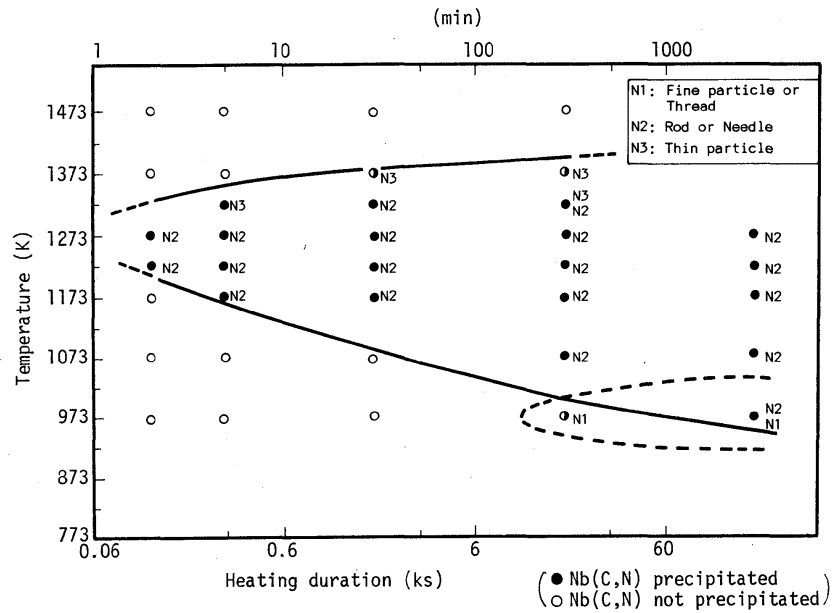

Fig. 12. Isothermal precipitation curves of $\mathrm{Nb}(\mathrm{C}, \mathrm{N})$ in $75 \% \mathrm{Ni}-15 \% \mathrm{Cr}-0.54 \% \mathrm{Nb}$ alloy after solution-treated at $1573 \mathrm{~K}$.

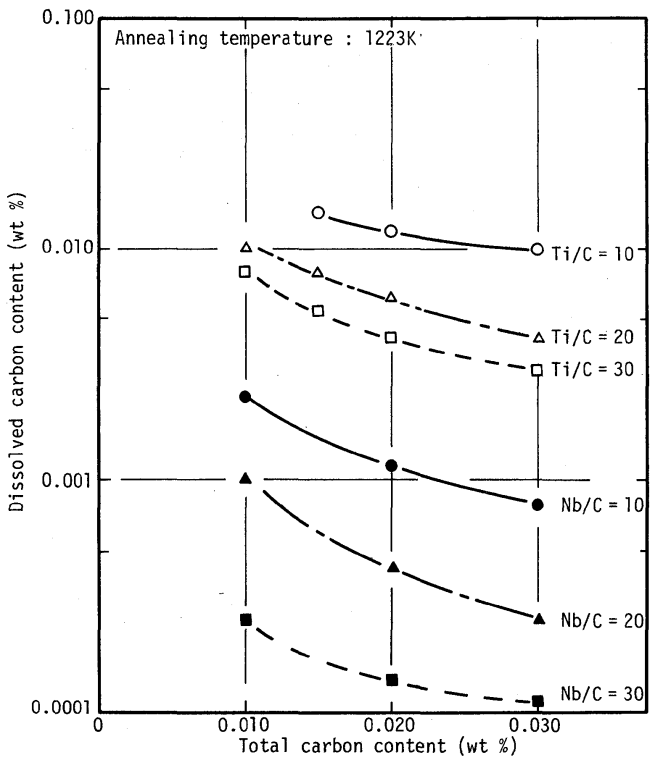

Fig. 13. Relationship between total carbon content and dissolved carbon content as a function of $\mathrm{Ti} / \mathrm{C}$ and $\mathrm{Nb} / \mathrm{C}$ ratio calculated from $\mathrm{Ti}-\mathrm{C}$ and $\mathrm{Nb}-\mathrm{C}$ solubility products.

\section{参 考 文 献}

1 ) R. C. Scarberry, S. C. Pearman and J. R. Crum, Corrosion, 32, 401 (1976).

2 ) 小若正倫, 長野博夫, 工藤起夫, 山中和夫, 岡田康孝, 南 孝男，防食技術，30，692（1981）.

3 ) M. R. Copson and G. Economy, Corrosion, 24, 55 (1968).

4 ) M. Kowaka, H. Nagano, T. Kudo, Y. Okada, M. Yagi, O. Takaba, T. Yonezawa and K. Arioka, Nucl. Tech., 55, 394 (1981).

5 ) 小若正倫, 長野博夫, 工藤赳夫, 山中和夫, 岡田康孝, 第26回腐食防食討論会予稿集，p. 196（1980）.

6 ) 岡田康孝, 吉川州彦, 行俊照夫, 日本金属学会誌, 45 , 496 (1981).

7 ）長野博夫, 工藤赳夫, 山中和夫, 南 孝男, 日本金属学 会, 昭和 56 年春期第 88 回講演大会予稿集, p. 268 (1981).

8 ) P. G. Stone, J. Orr and J. C. Guest, J. Br. Nucl. Soc., 14 25 (1975)

9 ) 山田武海, 学位論文 (東京大学) (1973). 